\title{
JUURNAL_RU
}

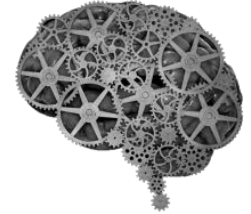

COMPANY GROUP "INTELLEKT"

\author{
Иванов П.А. \\ ГБОУ Школа №799 \\ Москва, Россия
}

doi: 10.18411/lj2016-3-55

\section{Воспитательный потенциал исследовательской деятельности школьников}

Одним их актуальных направлений развития школьного образования является широкое внедрение проектной и исследовательской деятельности. Это хорошо видно по тому, что конкурсы исследовательских работ включены в перечень значимых мероприятий Департамента образования, а значит, участие и победа в них дают школам рейтинговые баллы, от которых в конечном итоге зависит финансирование. Поэтому в ближайшее время каждая школа будет уделять всё большее внимание данному виду работ. Уже сегодня можно выделить ряд тенденций.

Наиболее важно то, что педагоги не вполне готовы к осуществлению такой работы. Они даже не вполне понимают, зачем она нужна. Поэтому многие работы выполняются учителями или родителями, а задача ребёнка - пересказать или даже прочесть её на конкурсе. Однако жюри всё активнее пресекают подобные нарушения. Поэтому стоит ожидать, что школы возьмутся всерьёз готовить учителей. Учителя же должны понимать, что такое проектная деятельность и какие задачи можно с её помощью решить.

О том, как эффективна проектная деятельность в плане обучения, сказано много, о воспитательном аспекте - куда меньше. Это противоречит принципу целостности образовательного процесса. Тем более, у каждого педагога есть учащиеся, для которых углублённое изучение предмета (проектная работа) 
бесперспективно, зато воспитания крайне не достаёт. Для таких учащихся стоит рекомендовать выполнение социально-значимого проекта, с глубоким социальным потенциалом.

Под проектом мы понимаем форму работы, которая осуществляется внеклассно, на протяжении длительного времени (от недели до нескольких лет). Его структура обладает всеми компонентами научной исследовательской работы. Если работа реферативная, её результат известен заранее, это проектная работа. Если результат изначально не известен, и проводится поиск принципиально новых данных - она называется исследовательской. Работа, направленная на творческую интерпретацию - это творческий проект, направленная на решение общественных задач - социально-значимый проект. Проекты может осуществлять один учащийся, или группа, или крупный коллектив из нескольких классов.

Проектная деятельность сама по себе несёт воспитательный потенциал:

- Проекты предполагают самостоятельность учащегося, в такой степени, на какую он максимально способен на текущем уровне развития. Работа в таких условиях способствует росту мотивированности, инициативности, ответственности учащегося, раскрытию его творческих способностей.

- Актуальность темы проекта способствует изменению отношения к учёбе в целом, когда учащийся воспринимает её не как бесполезную обязанность, но как возможность проявить себя, сделать что-то необычное, выйти за рамки школьной программы. Полезным может оказаться даже отказ от поощрения ученика оценками, в результате чего последний будет искать внутреннее, нравственное подкрепление и мотивацию для своей работы, убеждать себя и понуждать к работе. Поэтому тема работы должна быть непременно интересна для учащегося. Даже если для учителя тема скучна, то для подростка она может представляться в ином свете.

- Завершающее работу над проектом выступление на конкурсе означает необходимость проявить такие качества личности как собранность, 
смелость, концентрация, служит мотивом для работы над речью, внешним видом, поведением.

- Групповая и коллективная формы организации проектной деятельности способствуют социализации и представляют возможности для воспитания товарищества, умения работать в команде, коммуникативных качеств.

- Наконец, воспитывают тема проекта и его направленность. Темы, интересные подросткам, чаще всего связаны с общественной жизнью, ведь в этом специфика данного возраста - особая направленность на социум. Поэтому, сами того не желая, подростки способствуют собственному воспитанию. Например, подросток шутки ради заявляет, что его интересуют наркотики. В таком случае можно сделать проект по темам, завязанным на профилактику наркозависимости, на физиологическое действие и вызываемые осложнения, на социальные или исторические аспекты.

Исходя из указанных особенностей проектной и исследовательской деятельности как средства воспитания, для достижения максимального воспитательного эффекта, необходимо придерживаться следующих принципов:

- Минимальное участие взрослых, поиск наиболее интересной для ученика тематики проекта,

• тщательная подготовка к моменту выступления,

- поощрение учащегося к работе,

- организация работы в разных формах, их чередование (один проектиндивидуальный, другой - групповой),

- использование интересной подростку темы работы для ведения исследования в просоциальной плоскости.

Отдельно стоит обсудить социально-значимые проекты. Чтобы яснее уяснить их специфику, рассмотрим примеры таких проектов: 
1. Проект сбора батареек, или ртутных ламп и т.п. Граждане обязаны утилизировать опасные отходы определённым образом, а методы сбора зачастую функционируют не вполне эффективно. Этот пробел могут восполнить школьники, собирая батарейки разовыми акциями, или на постоянной основе, попутно информируя о том, куда следует сдавать отходы, которые нельзя выбрасывать.

2. Проект ухода за парком/сквером/мемориалом/памятником. В данном случае, проект - это форма организации шефской работы, адаптированная для современных условий. Плюс такого подхода в том, что шефство дополняется изучением всей возможной информации, связанной с объектом опеки (история создания, структура, функции и т.п.)

3. Проект сбора воспоминаний, например, о Великой Отечественной Войне, у ветеранов. Это сочетание шефской опеки и исторического исследования, позволяющее не только собрать уникальные материалы, но и помогает пожилым людям почувствовать себя востребованными, нужными обществу.

Такие социально-значимые проекты, позволяют организовать воспитание в деятельностной парадигме. В этом случае, подростки занимаются не просто учёбой, но важным и ответственным делом. Это важно подчёркивать, публично освещать, деятельность подростков в рамках проекта можно осветить в местной прессе, на телевидении. Таким образом можно дополнительно мотивировать подростков, и все компоненты воспитания, описанные выше: ответственность, инициативность, самостоятельность и т. п. - будут происходить более эффективно и на большей аудитории учащихся. 